\title{
História oral, oralidade e audiovisual na construção de relatos de memórias traumáticas
}

\author{
Dácia Ibiapina da Silva*
}

\section{Introdução}

A Guerrilha do Araguaia foi um dos mais importantes movimentos armados rurais já ocorridos no Brasil. Após o golpe de 1964 implantou-se no país uma ditadura militar que procurou, por todos os meios, sufocar os anseios da esquerda brasileira de mobilizar o país em torno de um projeto político de cunho socialista. Vários fatores levaram o Partido Comunista do Brasil (PCdoB) a organizar a Guerrilha do Araguaia, deslocando para esta região do país (sudeste do Pará e norte do atual estado de Tocantins, banhados pelos rios Araguaia e Tocantins) seus melhores quadros. $\mathrm{O}$ auge dos combates entre os guerrilheiros e as Forças Armadas Brasileiras ocorreu no período de 1972 a 1974.

Além dos guerrilheiros e dos militares que os combateram há, na Guerrilha do Araguaia, um terceiro conjunto de atores sociais que participou ativamente deste processo: a população da região do Araguaia. Esta comunicação é sobre as memórias da Guerrilha do Araguaia e prioriza pontos de vista expressos em entrevistas com pessoas da região onde aconteceu este movimento guerrilheiro. Dada a impossibilidade de ouvir todas as pessoas da região sobre suas experiências,

* Professora da Faculdade de Comunicação da Universidade de Brasília. 
pessoais e coletivas, durante a Guerrilha do Araguaia, foi necessário delimitar um lugar e um conjunto de narradores que o habitam. O lugar escolhido foi a cidade de Palestina do Pará, situada no sudeste do Estado do Pará, na margem direita do rio Araguaia, próxima ao local onde os guerrilheiros do Araguaia implantaram um de seus destacamentos (Grupamento B ou Grupamento da Gameleira). ${ }^{1}$ Os narradores são moradores de Palestina, com exceção de um senhor e de sua esposa que atualmente moram em Marabá, mas que têm vínculos com Palestina desde a época da guerrilha. Foram selecionadas para as entrevistas as pessoas que viveram experiências traumáticas durante a guerrilha e que concordaram em relatá-las diante de uma câmara de cinema ou de vídeo. Foram utilizadas também, como fontes complementares, entrevistas feitas por outros pesquisadores e por jornalistas com moradores da região sobre o mesmo tema, ${ }^{2}$ com o objetivo de comparar estes relatos anteriores com os mais recentes, feitos durante esta pesquisa comparação esta que permitiu perceber a temporalidade e circunstancialidade dos referidos relatos de memória. Palestina foi escolhida como o lugar das ações, da memória e da pesquisa, porque ali aconteceram fatos significativos historicamente durante a guerrilha e, também, pela facilidade de contatar lideranças comunitárias locais que se transformaram depois em aliados do projeto.

A opção pelo uso da linguagem audiovisual durante a construção dos relatos de memória dos entrevistados deveu-se a vários fatores. Em primeiro lugar, as experiências relatadas pelos narradores são de natureza traumática, de tal forma que os entrevistados demonstraram que lhes é difícil admitir que foram presos, torturados e humilhados durante a repressão à guerrilha. Muitos deles encontraram no silêncio ou em narrativas reticentes uma forma de expressar as dores do passado. Os relatos audiovisuais permitiram outras formas de comunicação e ex-

1 Os guerrilheiros do Araguaia estavam distribuídos em três destacamentos: A, B e C. O A ficava na localidade de Faveira, município de São João do Araguaia, no Pará. O B ficava na beira do rio Gameleira, próximo do povoado de Santa Isabel, no Pará. Finalmente, o destacamento C ficava na localidade de Caianos, próxima a São Geraldo do Araguaia, no Pará, e Xambioá, no Tocantins.

2 Foram utilizadas em especial entrevistas do acervo dos pesquisadores Romualdo Pessoa Campos Filho e Gilvane Felipe, realizadas entre 1992 e 1996, disponíveis no Instituto de Estudos Sócio-Ambientais da Universidade Federal de Goiás. 
pressão, para além do texto verbal, como por exemplo a troca de olhares entre o entrevistador e os entrevistados. Em segundo lugar, a oralidade é uma forma de comunicação privilegiada por este grupo de narradores, já que estão habituados a compartilhar entre si e com outros interlocutores, por exemplo os jornalistas e os pesquisadores, experiências vividas. São pessoas analfabetas ou de pouca leitura, que guardam na memória experiências dramáticas e imprevisíveis, vividas individual ou coletivamente, que encontram na oralidade uma forma de preservação da memória e da história locais. Finalmente, sou cineasta documentarista e iniciei esta pesquisa com o objetivo de fazer um filme documentário sobre o tema, o que efetivamente foi feito. ${ }^{3}$

Um dos objetivos da pesquisa era justamente tentar analisar as relações entre oralidade, história oral e audiovisual na construção dos relatos de memória dos entrevistados. Que contribuição pode trazer o audiovisual nestes casos? Que problemas adicionais coloca para a relação de pesquisa? Neste caso específico, quais os ganhos e perdas que desta opção metodológica? Estas questões serão tratadas no decorrer desta comunicação.

\section{A construção de relatos audiovisuais de memórias traumáticas: tempo e narrativa}

Fui à região do Araguaia em busca de homens e mulheres que vivem ali, para pedir-lhes que confiassem em mim e, em o fazendo, confiassem-me um naco de suas memórias. Não os escolhi por acaso, mas por acreditar que viveram experiências traumáticas, não planejadas, imprevisíveis em suas histórias de vida, provocadas pela Guerrilha do Araguaia. Fui atrás das marcas que estas vivências deixaram em suas memórias individuais e coletivas. Quis saber se mudaram ou não o rumo de suas vidas, se contribuíram para aumentar ou diminuir sua dificuldade de viver. Esta busca teve motivações científicas, estéticas e humanas. Meu objetivo não era desfrutar sozinha do privilégio de conhecer estas memórias. Queria registrá-las, interpretá-las, transformá-las em

3 Palestina do Norte: O Araguaia passa por aqui, filme documentário de curtametragem, de Dácia Ibiapina da Silva, 15 minutos, cor, Brasília, 1998. 
documentos para a história, compartilhá-las com os próprios narradores, com outros pesquisadores, estudantes e demais pessoas que se interessam por esta temática.

Os que me confiaram parte de suas memórias não o fizeram sem antes perguntar quem eu era, porque me interessava por suas histórias e o que pretendia fazer com elas. Expliquei que sou cineasta, professora, pesquisadora, que me interesso por histórias como as deles e que pretendia fazer primeiro um filme documentário e, depois, uma tese (Silva, 2002), a partir de seus relatos de memória. Como não estão acostumados com isso, logo pensaram em televisão, daí as perguntas inevitáveis: vai passar na televisão? Quando e em que canal? Apesar da dificuldade de explicar e justificar os meus motivos, conseguimos nos comunicar, estabelecer uma relação de confiança mútua, pautada por limites tênues, estabelecidos tacitamente, que permitiram a emergência das narrativas de memórias que são objeto desta comunicação. Os grandes desafios desta pesquisa foram, em primeiro lugar, interagir com os entrevistados de forma a possibilitar a emergência de seus pontos de vista e de suas representações sobre a Guerrilha do Araguaia, e o passo seguinte - a escrita - a construção de uma interpretação sobre estas memórias locais, a partir da reflexão crítica sobre este conjunto de narrativas nas quais estou profundamente implicada, já que propus as entrevistas e as conduzi.

O tema desta pesquisa não foi a Guerrilha do Araguaia, enquanto tal, mas os relatos de memória feitos pelos moradores da cidade de Palestina do Pará, gravados em vídeo ou em película. Trata-se de uma interpretação da memória local, a partir dos relatos, que por sua vez são também interpretações. Não tive a pretensão de estabelecer verdades sobre a Guerrilha do Araguaia, nem de reescrever sua história, mas sim de analisar as memórias e interpretações que estão presentes nos referidos relatos e, a partir delas, construir uma outra interpretação. Segundo o filósofo francês Paul Ricoeur, interpretação: "é o trabalho de pensamento que consiste em decifrar o sentido oculto do sentido aparente, em desdobrar os níveis de significação implicados na significação literal. [...] há interpretação onde houver sentido múltiplo; e é na interpretação que a pluralidade dos sentidos torna-se manifesta." (Ricoeur, 1978, p.15). O trabalho de interpretação realizado nesta pesquisa consistiu em identificar e analisar, nos relatos, a constituição de processos 
de significação e de atribuição de sentidos que vão além do sentido literal do que estava sendo relatado. Ao fazer isto, estou também, como pesquisadora, constituindo novos processos de significação.

Ao realizar esta pesquisa, pude perceber, na prática, que a memória é uma reinterpretação constante. No caso da memória local sobre a Guerrilha do Araguaia, as interpretações são múltiplas, mutáveis com o tempo, com as preocupações do momento e com as condições de interlocução. Pude perceber também que a Guerrilha do Araguaia assume significados e suscita elaborações de memórias e interpretações específicas dependendo, entre outros fatores, das vivências dos atores sociais que as narram: guerrilheiros sobreviventes, militares que os combateram, moradores da região e diversos segmentos da sociedade brasileira que se manifestaram e continuam a se manifestar sobre ela, inclusive os pesquisadores. São enfocadas, neste trabalho, as memórias e interpretações dos moradores da região entrevistados. Os relatos construídos durante esta pesquisa contêm temas, fatos e representações que são recorrentes, ou seja, aparecem em relatos feitos por diferentes narradores ou em relatos feitos pelo mesmo narrador em momentos diferentes, ou ainda, de forma repetida, durante um relato mais longo.

Com base nestas recorrências, a Guerrilha do Araguaia, para as pessoas da região, significou uma "guerra" na qual elas foram envolvidas, uma etapa importante na luta que travam cotidianamente pela sobrevivência material, psicológica, cultural e social, no interior de uma sociedade desigual, onde se vêm como "os fracos de condição", outra forma de denominar os excluídos sociais. Para estas pessoas, "a luta continua" e a "guerra" pode voltar a qualquer momento, assim como começou e terminou anteriormente. Sentem-se inseguros e à mercê dos mais fortes: do Estado, das políticas públicas, de nós todos que somos vistos por eles como "os fortes de condição", inclusive os pesquisadores. Os termos "os fracos de condição" e "os fortes de condição" foram utilizados pelo senhor José Francisco de Carvalho, conhecido como Zé Maroca, um dos moradores de Palestina do Pará entrevistados. O termo "os fracos de condições" aparece também em um cântico que faz parte do hinário das quebradeiras de coco da região denominado Xote das Quebradeiras de Coco. Estes termos podem ser vistos como categorias construídas localmente que permitem aos que as utilizam se situar sócio-economicamente. 
As memórias da Guerrilha do Araguaia, neste conjunto de narrativas audiovisuais, aparecem associadas a outras, diretamente relacionadas com certos aspectos das histórias de vida dos narradores. Como são migrantes, suas memórias da guerrilha inscrevem-se no contexto mais amplo da memória da migração e da luta pela sobrevivência individual e coletiva. A região onde aconteceu este movimento guerrilheiro, no início dos anos 70 do século passado, recebeu um grande contingente de migrantes vindos de outras regiões do país, especialmente do Nordeste e do norte de Goiás, atualmente estado do Tocantins. Estas pessoas deslocaram-se para esta região em busca de terras onde pudessem se estabelecer como pequenos posseiros ou como colonos nos processos de ocupação desta região amazônica, planejados e empreendidos pelo Estado de então. Muitos fizeram uma longa viagem que os levou até ali, onde defrontaram-se com a guerrilha, bem como com grandes projetos rodoviários, madeireiros, agropecuários, de mineração, etc., desenvolvidos pelos governos militares. Seus relatos de memória remetem-nos ao entrelaçamento de fios de memórias que se encontram no tempo e lugar onde aconteceu a Guerrilha do Araguaia.

Os entrevistados demonstraram ter dificuldade de contextualizar a Guerrilha do Araguaia, do ponto de vista histórico e político-ideológico. Como estavam à margem das discussões e conflitos políticos que marcaram o período no Brasil e no mundo, era-lhes difícil distinguir, por exemplo, ditadura de democracia, esquerda de direita, capitalismo de socialismo, bem como entender porque aconteceu uma guerrilha na região onde moravam. A repressão e a censura políticas empreendidas pela ditadura militar de então contribuíram para tornar-lhes ainda mais inacessível esta compreensão. Como estavam envolvidos no processo, foram, aos poucos, construindo suas próprias interpretações e representações sobre as experiências vividas. A guerrilha era apenas uma das suas frentes de luta para "escapar com vida" na região na época. Além do fogo cruzado entre os guerrilheiros e os militares que os combateram, havia também a luta para manter-se na terra, a luta contra a fome, o analfabetismo, o isolamento, as doenças e tantas outras. Este é um dos motivos pelos quais as experiências traumáticas e imprevisíveis vividas durante a guerrilha e diretamente relacionadas com ela, foram incorporadas em suas memórias como um dos aspectos de sua luta cotidiana pela sobrevivência. 
Para abordar estes aspectos dos relatos, foram utilizados dois textos que tratam da mesma questão em outros tempos e lugares: Os parceiros do Rio Bonito: estudo sobre o caipira paulista e a transformação dos seus meios de vida (Cândido, 1982) e A miséria do mundo (Bourdieu, 1997). O primeiro autor fez um estudo da "sociologia dos meios de subsistência" ou do "problema dos meios de vida" do caipira paulista, ressaltando o peso da luta deste grupo social para subsistir. Bourdieu, por sua vez, juntamente com uma equipe de sociólogos, debruçou-se sobre o estudo das condições de produção da subsistência em lugares que qualifica como "difíceis de descrever e de pensar", em centros urbanos como Paris e Chicago, em época recente (início dos anos 90 do século passado). Estes dois estudos estimularam-me a considerar seriamente, na pesquisa, as relações estabelecidas pelos narradores entre as memórias da guerrilha e outras, como por exemplo, a memória da migração e da luta pela sobrevivência do dia-a-dia na região, na mesma época.

Outro aspecto dos resultados desta pesquisa, a ser ressaltado, é a dificuldade que os entrevistados tiveram para narrar suas memórias do tempo da guerrilha, devido à sua natureza traumática, bem como a aspectos sócio-culturais locais. Os relatos construídos estão marcados por silêncios, pausas, hesitações, sofrimento. Ao entrarem novamente em contato com as dores do passado, os narradores atualizaram também os sentimentos da época: medo, raiva, humilhação, impotência. Para os entrevistados, foi particularmente difícil admitir e relatar a tortura. Muitos foram os que narraram a tortura sofrida por outros, mas poucos os que admitiram que foram torturados pessoalmente. A provável tortura sofrida no próprio corpo, foi silenciada ou transferida para o corpo do outro. Parte da dificuldade de assumir a condição de preso político e de torturado, por este grupo de narradores, deve-se a processos de construção de identidade que acontecem pari e passu com a construção dos relatos de memória, como já foi afirmado por alguns estudiosos da memória, como por exemplo, Michael Pollak (1992, p. 200-15). Na construção da identidade masculina dos moradores da região do Araguaia/Tocantins, os homens devem ser fortes e destemidos e não devem se deixar humilhar ou enganar. Como então admitir e relatar a tortura sofrida no próprio corpo sem comprometer a auto-imagem e a imagem pública? Na minha interpretação, este é um dos fatores pelos quais a tortura configura-se como uma experiência difícil de 
relatar, indizível ou inexprimível, para os homens entrevistados, bem como para os seus familiares. Existem também outros fatores que ajudam a explicar e a compreender este silêncio, que foram identificados durante a pesquisa, mas que não cabe explicitar aqui, no curto espaço desta comunicação.

Encontrei em Michael Pollak um conceito adequado para interpretar a dificuldade que estes narradores têm de romper o silêncio e expressar o trauma que a tortura representa em suas memórias, por meio da linguagem. É a idéia de "gestão do silêncio". Segundo este autor, quem passou por experiências traumáticas e as considera difíceis de comunicar, "indizíveis" mesmo, não as esquece e necessita encontrar formas e estratégias para seguir vivendo, com elas e apesar delas. É o que denomina de "gestão do indizível" (Pollak, 1986, p. 30-53). A seguir, serão abordados alguns aspectos da "gestão do silêncio" deste grupo de narradores.

\section{Uma referência ao lugar do silêncio em relatos de memórias traumáticas}

Aprendi muito sobre o silêncio e seu lugar nos relatos de memórias traumáticas durante esta pesquisa. Descobri que, neste caso específico, o silêncio dos entrevistados revelou-se circunstancial, temporal, sujeito a vários tipos de injunções, inclusive as de ordem material, como por exemplo, a necessidade de relatar as agruras do passado para justificar um pedido de indenização junto ao Estado. Foi surpreendente observar como os próprios narradores, a seu modo, têm plena consciência de que são sujeitos de suas memórias e de seu silêncio, que podem e devem geri-lo, dependendo da confiança que depositam nos interlocutores e do decorrer do tempo. Tanto é assim que criaram suas próprias temporalidades para abordar o tema da guerrilha, dito por eles "tempo de passar ri-ri na boca"4, "tempo do fala baixo", "tempo de cochichar". Para eles, hoje, ou seja, o tempo da pesquisa, é o "tempo de falar".

4 Na região, "ri-ri" significa zíper. 
Demonstraram igual sabedoria sobre a gestão do silêncio quanto ao seu conteúdo. Admitem que não contam tudo o que viveram na época, mas apenas o que acreditam que pode e deve ser relatado sem prejudicar a auto-imagem e a imagem pública do narrador. Decisão esta que geralmente vem acompanhada de grande sofrimento. Dona Felicidade, uma das entrevistadas, disse que "ninguém conta sofrimento assim, detalhe por detalhe, de cada instante da vida da pessoa". Luzinete, outra entrevistada, disse acreditar que: "ninguém conta por inteiro a história de uma vida!"

Também foi um aprendizado constatar os aspectos sócio-culturais do silêncio dos narradores. Eles relacionam, por exemplo, seu silêncio com sua condição de analfabetos. Trata-se de uma forma perspicaz que encontraram para afirmar sua cultura, frente à cultura letrada do interlocutor, além de ser também uma forma de denunciar a própria exclusão social. Quando lhes convém, negam-se a falar sobre a guerrilha, afirmando que são analfabetos e que, "quem é analfabeto não sabe de nada", por esta razão, deve silenciar. Seu silêncio é denso, formado por camadas temporais, espaciais e mesmo luminosas, o que ficou bem evidenciado na versão audiovisual original dos relatos. Há o que deve e o que não deve ser conversado no terreiro ou na porta da casa, no lusco-fusco de uma boca de noite; o que deve ser conversado na sala de visitas, quando o pesquisador é tratado como um visitante; bem como o que convém ser cochichado na cozinha ou à sombra de uma árvore no quintal da casa, com os íntimos (o pesquisador pode chegar a ser um deles).

O que é silenciado em uma primeira entrevista, pode muito bem ser enunciado em outra, em outro tempo e lugar. Cabe ao pesquisador perceber estas nuances, adequar-se a suas temporalidades e espacialidades, bem como às nuances de gênero, pois há também o que pode ser conversado "de mulher pra mulher" e "de homem pra homem". O conteúdo e a qualidade de uma entrevista gravada às pressas, na porta da casa, com o entrevistado cercado de curiosos, sob um sol forte, são nitidamente diferentes dos de um relato gravado na cozinha ou no quintal da casa do entrevistado. $\mathrm{O}$ pesquisador deve esperar ser admitido em cada um destes espaços e, geralmente, tem que passar por todos eles, antes de chegar naquele que lhe convém, no meu caso, a cozinha ou o quintal. Os espaços do trabalho também revelaram-se favorecedores da 
intimidade entre o pesquisador e os entrevistados. Observei que, no caso das mulheres, com as quais tinha mais intimidade, quando estavam lavando roupa, cozinhando, quebrando coco, raspando mandioca, pescando na beira do rio, etc., doía-lhes menos relatar suas experiências traumáticas. Não tenho a pretensão de generalizar estas observações, pois são também circunstanciais, tal qual o silêncio dos entrevistados. São frutos de uma experiência de pesquisa específica, agora sedimentados em minhas memórias de cineasta e pesquisadora. São contribuições deste trabalho para o debate sobre os estudos de memória.

\section{Aspectos narrativos dos relatos audiovisuais de memória construídos durante esta pesquisa}

"Bom gente, aqui no Araguaia aconteceu uma guerra, uma época, aí meu marido foi preso, nesse tempo... o Exército levou ele por umas duas vezes."

É assim que Lisbela Maria da Conceição inicia seu relato de memória sobre a Guerrilha do Araguaia, feito em outubro de 1997, em Palestina do Pará. A forma que utiliza para iniciá-lo lembra o topos "era uma vez" e anuncia a natureza de sua fala, claramente narrativa, no sentido do que Walter Benjamin chama de narração. Para ele, a arte de narrar diz respeito à faculdade humana de intercambiar experiências. "A experiência que passa de pessoa a pessoa é a fonte a que recorrem todos os narradores. E, entre as narrativas escritas, as melhores são as que menos se distinguem das histórias orais contadas pelos inúmeros narradores anônimos" (Benjamin, 1987, p. 198). Entre as características do narrador, Walter Benjamin destaca as seguintes: tem sempre raízes no povo; tem senso prático; é um homem simples; sabe dar conselhos, ou seja, tem sabedoria; geralmente se dedica a trabalhos artesanais; a narrativa tem sempre uma "moral da história", que pode ser interpretada e apropriada de várias maneiras; o destino da narrativa é ser memorizada e reproduzida pelos ouvintes; o melhor estado de espírito para ouvir, memorizar e narrar é o tédio, por isso a prática de atividades artesanais e tediosas, tais como fiar, tecer, polir, etc., favoreceriam o dom narrativo. Segundo Benjamin, o narrador mergulha a 
experiência narrada em sua própria vida, ou na de quem a viveu: "Assim se imprime na narrativa a marca do narrador, como a mão do oleiro na argila do vaso" (Benjamin, 1987, p. 205), por isto ele considera a narrativa uma forma artesanal de comunicação.

A forma como os moradores de Palestina do Pará contam suas lembranças do tempo da guerrilha aproxima-os deste narrador benjaminiano. São narrativas orais, feitas por pessoas não letradas ou de pouca leitura, com base em experiências vividas individual ou coletivamente, por elas próprias ou por outras, em uma situação de conflito armado. Os fatos e emoções narradas aproximam-nos, porém a forma de narrar e de agregar elementos da experiência pessoal à narrativa tornam-nos únicos. Do ponto de vista dos tipos característicos de narradores mencionados por Benjamin (o viajante e o camponês sedentário), os entrevistados nesta pesquisa se encaixariam no primeiro tipo, já que são migrantes e, como lembra este autor, "quem viaja, tem muito que contar" (Idem, p. 198).

Lisbela, mencionada anteriormente, por exemplo, como outras mulheres que moravam na região do Araguaia na época da guerrilha, teve o marido preso e torturado. Relata que sentia muito medo e que os vizinhos tinham receio de ajudá-la e ampará-la, com suas crianças, pois tinham medo de também se comprometer. Destaca que estava grávida quando ele foi preso e que teve o filho sozinha, na companhia de suas crianças mais velhas, pois ninguém se dispôs a ajudá-la na ocasião. Lisbela contou também que, quando escurecia, seu medo aumentava, que as crianças dormiam cedo e que ela ficava acordada, sozinha, até se entregar ao sono, por puro cansaço. Outros narradores, homens que foram presos e torturados, contam que, depois de libertados, tinham acessos de pânico ao ouvir sons de carros, de helicópteros, pisadas de botinas de soldados.

Cícero Pereira Gomes, atualmente com 68 anos, vive em São Geraldo do Araguaia, onde foi contatado pelo Exército em 1973, tendo sido então recrutado para trabalhar como "guia"5. Recentemente, contou ao jornal Correio Braziliense que assistiu à morte do guerrilheiro

5 "Guia" é o termo utilizado para designar o morador da região que foi recrutado pelas forças da repressão à guerrilha para orientar as patrulhas militares durante seu deslocamento na mata. 
Adriano Fonseca Fernandes, ${ }^{6}$ conhecido como Chicão ou Queixada: "Ele foi morto por Raimundinho com um tiro de espingarda no peito, a mando do tenente que comandava a operação. [...] Quando recebeu a bala, o Chicão botou a mão no rosto e deu um gemido doído que até hoje parece que escuto" (Correio Braziliense, 28/11/2001). O atirador era morador da região e, depois de matar o guerrilheiro, cortou-lhe a cabeça. Cícero conta que ajudou a carregá-la em um saco, pelo meio da mata, e completa: "pesava tanto que parecia um corpo inteiro". Como se nota, a memória deste narrador foi impregnada por certas sensações, que retornaram por ocasião do relato. Ele disse que tem a consciência pesada, que não quer morrer sem antes contar tudo o que viu, que tem problemas de saúde - hipertensão - e que tem uma sensação estranha na barriga: "É como se um sapo estivesse passeando dentro de mim".

No conjunto de relatos de memória aqui analisados, pode-se observar diferentes aspectos narrativos. Dois dos entrevistados compararam suas histórias de vida com "romances". Dona Felicidade, esposa do senhor Otacílio Alves de Miranda, conhecido como Baiano, após uma observação minha de que a história que eles viveram e que estavam relatando era uma longa história, afirmou:

“É. É um romance. É um romance. E é porque a pessoa conta por alto, porque, como se diz, muito detalhe, não adianta, a pessoa conta tudo por... porque ninguém conta sofrimento assim, detalhe por detalhe, de cada instante da vida da pessoa... é uma longa história... foi uma coisa muito terrível." (Entrevista concedida a esta pesquisadora em Marabá/ PA, em 27/01/2001)

A noção de romance também foi evocada pelo senhor Cícero Saraiva da Silva, conhecido na Palestina como Seu Generoso, que também afirmou que sua história "dá um romance". Estes entrevistados identificam elementos em suas histórias de vida que os permitem compará-las com romances. Que elementos seriam estes? Que noção de romance estariam utilizando? Walter Benjamin, no texto mencionado

6 "Nascido em Ponte Nova, Minas Gerais, Adriano participou do movimento estudantil no Rio de Janeiro, entrou para a Faculdade de Filosofia em 1969, passando a militar logo depois no PC do B. Em 1971, deslocou-se para a região do Araguaia, onde morreu aos 23 anos. (Miranda \&. Tibúrcio, 1999, p. 182). 
anteriormente, define o romance em oposição à narrativa. Este seria uma forma narrativa escrita, característica da modernidade, diferente portanto do conceito utilizado por estes narradores. Algumas pistas estão inscritas em suas próprias falas. Em primeiro lugar, aparece a questão da duração da narrativa. Suas histórias são como romances porque são "longas histórias". Em segundo lugar, aparece o sofrimento. São histórias dramáticas, marcadas pelo sofrimento dos que as viveram. Dona Felicidade menciona também a presença dos detalhes. Seu Generoso, por sua vez, enfatiza as idas e vindas. Sua história é marcada por andanças entre o Nordeste e o Norte. É uma história de andarilho, de viajante, de migrante, como a de muitos outros moradores da região, inclusive a do marido de Dona Felicidade. A inserção sócio-cultural destes narradores também traz outras pistas sobre sua noção de romance. Eles são analfabetos ou de pouca leitura, não tendo, portanto, familiaridade com romances escritos. Certamente a noção de romance utilizada pelo Seu Generoso e por Dona Felicidade deve ser buscada na tradição narrativa oral e popular, nas canções e romances populares, não na literatura dita culta ou erudita. Um romance, na perspectiva deles, se caracteriza por ser uma história onde se sobressaem as rupturas na mesmice do cotidiano.

Ao contar suas memórias, marcadas por acontecimentos dramáticos, vividos em cenários que alternam o "lugar ameno" (o vilarejo pacato na beira do rio) com a "paisagem épica"7 (a floresta selvagem ou a "brabeza"), estes narradores agregam elementos retóricos à narrativa que os remetem e nos remetem, por um lado, ao tempo em que a história era considerada um ramo da retórica e, por outro, à discussão atual sobre o retorno da narrativa histórica, complementar à história explicativa ou "científica" (Stone, 1979, p. 3-24; Lacerda, 1994, p. 9-42). Ao identificar elementos de um romance em suas histórias de vida, constroem também uma noção própria do que seja romance. Para eles a guerrilha forneceu talvez a trama principal do "romance" em que se transformaram suas vidas.

O romance não é entretanto a única forma narrativa ou "espetacular" que as experiências da época da guerrilha trazem a este conjunto

7 "Lugar ameno" e "paisagem épica" são dois topos de linguagem. (Curtius, 1979, p. 202-9). 
de narradores. Alguns compararam também as histórias vividas na época da guerrilha com novelas, por serem dramáticas, surpreendentes e inacreditáveis. Aqui, no meu entendimento, a comparação não difere da anterior, com o romance.

Para o senhor Antonio Francisco de Melo, conhecido na Palestina como Seu Antonhão, participar da guerrilha foi como participar de um espetáculo circense de vôo da morte. Diz ele:

"Aqui era... eu não sei do princípio, e nem quais as origens, agora, por essas origens... entrou muito inocente, viu. Eu tenho certeza que não era... eu pelo menos entrei... mas..., não quiseram dar fim em mim... eu pelo menos não tenho medo de perder a vida não, porque, é a que eu tenho. Eu... não tenho decoro, eu converso o que for preciso, não tenho medo. Eu saí... fora. Mas quem entra naquele movimento... aquilo, podemos empregar... o vôo da morte. Porque do vôo da morte, você sabe, não escapa, é difícil.

Pois é. Eu entrei no vôo da morte. E o que entrou e saiu, saiu tudo inutilizado, já quase morto, baqueado..." (Entrevista concedida a esta pesquisadora em Palestina do Pará, em 30/01/2001).

Ao recorrer a esta metáfora, Seu Antonhão está ressaltando o caráter trágico e dramático das experiências vividas por ele e por outros que foram presos e torturados. Ele buscou em um espetáculo circense a imagem que, para ele, melhor exprime a natureza daquelas experiências, demonstrando que o circo, uma das formas de manifestação da cultura popular, faz parte do universo destes narradores. O lugar das ações, neste caso, é comparado ao picadeiro. Uma prova de que havia espetáculos circenses na região, na época, é a prisão de um artista de circo, em 1972, em São Domingos do Araguaia, juntamente com um padre e uma freira. Segundo o relato do padre que foi preso - Padre Roberto de Vallicourt - este "lutador de circo" teria sido preso porque estava "cabeludo". 8 Denominar o artista de circo de "lutador" e "ca-

8 Conforme entrevista concedida a Romualdo Pessoa Campos Filho e Gilvane Felipe, em Marabá - Pará, em 16/01/1994, gentilmente cedida a esta pesquisadora. 
beludo" contribui para reforçar a metáfora anterior. Os guerrilheiros, como o "lutador de circo", usariam cabelos longos, seriam "lutadores" e deveriam ser presos pelo Exército. Haveria, de fato, afinidade entre o circo e a guerrilha: lugares de luta, de perigo, do "vôo da morte", da diferença estética e de valores.

Alguns entrevistados compararam as experiências vividas no tempo da guerrilha com "processos", no sentido de acidente, atribulação, provação, tormento, sofrimento. O senhor José Alves da Silva, conhecido como José de Belém, usou o termo "trânsito", querendo provavelmente dizer transe:

"Pois é, Dona Maria! Quando a gente tem que passar por um trânsito na vida, no dia que a pessoa nasce, já vem marcado o que ela há de passar. É... não tem jeito... chega aquela época, o sujeito passa. Mas... foi uma das coisas... que eu passei na minha vida, mas não gosto nem..." (Entrevista concedida a esta pesquisadora em Palestina do Pará, em 08/ 02/2001).

O senhor José Matias dos Santos, conhecido como Zé Roxo, usou especificamente o termo "processo" enquanto narrava o que passou em uma noite em que esteve preso na Bacaba:

"Êeeehhh, processos e processos, mas é assim mesmo... tristeza não paga nada não, não resolve nada, aí sim, pode ser... aí eu entrei, que quando eu entrei, já de noite... êeehhh menina! Não há vida sem acidente, mocinha! Não há vida sem acidente, tribulação ou provação, você concorda?

Dácia: Concordo sim, senhor!

Seu Zé Roxo: Neste planeta terra, sem acepção, sem cor, sem nada... todos têm que passar por um processo, aqueles que têm mais um... um poder, mas amanhã chega a vez dele, não chega?" (Entrevista concedida a esta pesquisadora, em Palestina do Pará, em 07/01/2001).

Este mesmo entrevistado afirmou também que o "processo" pelo qual passou "não tem datilógrafo que datilografe, não tem escritor que imprima". Seu Zé Roxo fez questão de demonstrar, no decorrer de seu 
depoimento, ser um narrador que tem "estilo": mencionou Camões e Rui Barbosa"; usou palavras e expressões "difíceis" (amenizar; acepção; fidalgo; "zanzanete"; "cranizar"; "objetivo, sentido e resultado"; "homem leigo, indolto, iletrado"; "desneutralizado"; militarismo, "retrospectizar", etc.); disse que já foi entrevistado por outras pessoas, por exemplo, o Coronel-Aviador Pedro Corrêa Cabral, que atuou como piloto de helicópteros durante a Guerrilha do Araguaia e que escreveu um livro sobre o tema (Cabral, 1993). Disse também que, durante o depoimento, estava representando um papel:

"Seu Zé Roxo: Papel, olha! E era um barracão rapaz, numa altura mais ou menos, numa largura mais ou menos. A menina entendeu que é um papel que eu tô fazendo? Mas não é um papel destes de almaço não. É... fazer uma comparação. Como é o nome?

Dácia: Representar.

Zé Roxo: Será que é a primeira vez que eu sei o que é gravar? Ei, menina! Caça uma Kodak aí, tira a foto e fotografa eu aí!"

Seu Zé Roxo comparou também o seu relato com uma fita gravada. Disse ser conversador e que, quando diz uma coisa, o faz várias vezes: "recapitulo as partes, passo a fita e repasso". Afirmou que a dor do passado retorna com a narrativa: "Oh! Menina! Isto doía em minha mente e ainda hoje, como quem tá 'ao vivo' hoje, parece que eu tô lá, naquele momento lá, hoje.” Emocionou-se várias vezes, ficava arrepiado e coçava-se. Justificou-se dizendo que "cada pessoa tem um aspecto".

O termo "processo" também foi utilizado pelo senhor Otacílio Alves de Miranda, conhecido como Baiano, já mencionado anteriormente. O sentido aqui é ligeiramente diferente. Ele chama de "processo" um conjunto de dois documentos escritos: uma "carta-depoimento" onde conta sua história de vida, com ênfase no período em que esteve preso durante a Guerrilha do Araguaia; e um atestado médico

9 Observei que Camões, Rui Barbosa e a Bíblia são referências para estes narradores. Costumam recorrer a elas para legitimar suas idéias. Seu Zé Roxo disse que ia dizer-me algo "em sinal de mim, dizia Rui Barbosa". Outros entrevistados também recorreram a estas referências. 
que lhe foi conferido por médicos que o operaram de um tumor no cérebro no Hospital das Clínicas em São Paulo. Este tumor seria, segundo ele, uma seqüela das torturas, especialmente dos choques elétricos aos quais foi submetido no PIC (Pelotão de Investigações Criminais) de Brasília. O Baiano costuma fornecer cópias destes documentos aos que o procuram para entrevistá-lo. É uma estratégia que usa para tentar evitar o esforço narrativo que, no seu caso, implica entrar em contato com as dores e emoções do passado.

Quando o procurei para entrevistá-lo, na manhã de 27/01/2001, em sua casa, em Marabá, encontrei-o cochilando à sombra de uma árvore na porta da casa. Ele recebeu-me e disse que não concordaria em gravar uma entrevista, pois já não lembrava de muito do que viveu no tempo da guerrilha, que já tinha dado muitas entrevistas e que estava decidido a não mais falar sobre este assunto. Ficamos conversando sobre outros temas até que, ao final de nossa conversa, ele disse que, quem sabe, se eu aparecesse em uma "boca de noite", poderíamos conversar sobre a guerrilha. Aproveitando a deixa, sugeri que nos encontrássemos naquela mesma noite, para gravarmos sua entrevista. Ele concordou. Porém, à noite, quando cheguei com os equipamentos de gravação, ele falou que tinha mudado de idéia, que tinha decidido não dar a entrevista e que, em compensação, me oferecia uma cópia de seu "processo". Disse que tudo que eu queria saber encontrava-se ali. Eu aceitei suas desculpas, recebi a cópia dos documentos e guardei-os.

A família estava reunida na porta da casa para a habitual conversa de "boca de noite". Dona Felicidade - esposa do Baiano - convidoume para sentar com eles e conversar. Aceitei seu convite. Começamos a falar de coisas triviais: como descobri onde moram, de onde sou, onde estava hospedada em Marabá, etc. Fomos conversando, conversando, até que Dona Felicidade convidou-me para entrar, conhecer a casa, conversar dentro da casa. Percebi que para ela, o que se conversa na porta da casa é diferente do que se conversa em seu interior, onde há mais intimidade. Sentamo-nos em sua sala de visitas. O Baiano nos acompanhou e juntou-se a nós. Dona Felicidade começou a contar-me suas lembranças do tempo da guerrilha, "tempo de sofrimento e provação". Revelou-se uma narradora excepcional. Fez um relato cheio de detalhes e de interpretações dos fatos narrados, numa linguagem simples e que considero poética, pois evocou em mim um turbilhão de 
imagens, sentimentos e emoções. O Baiano ouviu o relato da esposa, atento, fazendo, vez por outra, reparos. Sorria de vez enquanto, pois o que a esposa contava, afinal de contas, era sua história de vida e a de sua família. A certa altura da narrativa de Dona Felicidade, interrompia e pedi para gravar seu relato. Ela concordou e sugeriu que fôssemos para a cozinha. Um sinal de que fui admitida plenamente em sua casa e em suas memórias. Enquanto posicionava a câmara e a luz, pedi ao Baiano que ficasse na posição onde iria ficar Dona Felicidade, para a gravação de seu depoimento. Ele aceitou de bom grado e ali permaneceu. Entendi que queria ser gravado. Coloquei outra cadeira ao seu lado, onde se sentou Dona Felicidade. Os dois começaram então uma luta para definir o quão próximos queriam ficar, ou não. Ele puxou a cadeira dela, para que ficassem mais próximos. Ela a afastou um pouco mais.

A esta altura, eu já estava gravando. Percebi que tinha, diante da câmara, um sutil conflito familiar e de gêneros. Pedi para Dona Felicidade apresentar-se. Era-lhe difícil. Ajudei-a com perguntas: qual era seu nome? Onde nasceu? Quantos anos tem? Seu Otacílio aproveitou a deixa e desandou a falar. Dona Felicidade calou-se e passou a ouvi-lo com atenção, fazendo reparos eventuais. Inverteram-se os papéis. Como já foi entrevistado várias vezes, Seu Otacílio tem mais facilidade para contar suas memórias. Começou a fazê-lo mecanicamente, cuidando-se para não entrar em contato com as emoções do passado. Travamos a clássica e tensa batalha entre entrevistador e entrevistado: eu, puxando pelo relato visceral; ele, pelo informativo. Aos poucos, a tensão foi-se dissipando. Ele contou sua história de vida e a fechou em grande estilo: “acabou, esta é a minha história”. Dona Felicidade emendou: “acabou nada! Agora vou contar a minha!"; e desandou a falar, trazendo o outro lado da história, o doméstico. Contou de sua luta, de sua coragem, de como sofreu com suas cinco crianças, todas mulheres. Enquanto ouvia seu relato, pensava o quanto seu nome é emblemático. Lembra-me Agrado, personagem criado pelo cineasta Pedro Almodovar para o filme Tudo Sobre Minha Mãe. Como uma mulher tão sofrida pode chamar-se Felicidade? Os relatos feitos por este casal são uma comprovação de que a memória, como disse Michael Pollak, "são percepções da realidade", sujeita a todo tipo de injunções, uma interpretação constante. 
Alguns relatos contêm também, em seu interior, pequenos contos. Por não se adequarem à natureza desta comunicação, serão tratados oportunamente, e ficaram excluídos deste texto.

\section{Questões teórico-metodológicas}

Como disse Pierre Bourdieu:

"Ainda que a relação de pesquisa se distinga da maioria das trocas da existência comum, já que tem por fim o mero conhecimento, ela continua, apesar de tudo, uma relação social que exerce efeitos (variáveis segundo os diferentes parâmetros que a podem afetar) sobre os resultados obtidos. Sem dúvida a interrogação científica exclui por definição a intenção de exercer qualquer forma de violência simbólica capaz de afetar as respostas; acontece, entretanto, que nesses assuntos não se pode confiar somente na boa vontade, porque todo tipo de distorções estão inscritas na própria estrutura da relação de pesquisa. Estas distorções devem ser reconhecidas e dominadas; e isso na própria realização de uma prática que pode ser reflexiva e metódica, sem ser a aplicação de um método ou a colocação em prática de uma reflexão teórica." (Bourdieu, 1997, p. 694)

A construção de relatos audiovisuais de memória implica a existência de uma equipe de filmagem ou de gravação, bem como do equipamento utilizado, que interferem substancialmente na relação entre o pesquisador e os entrevistados. Cabe ao pesquisador reconhecer e dominar estas interferências durante a construção dos relatos. Equipes e equipamentos de gravação audiovisual exercem grande fascínio sobre as pessoas, especialmente em lugares onde raramente aparecem, como por exemplo, em Palestina do Pará. Não se podia esperar que passem despercebidos e, neste caso, a opção foi informar aos potenciais entrevistados da metodologia de trabalho, das necessidades da equipe e do equipamento, bem como dos objetivos da pesquisa. Os entrevistados, por sua vez, queriam saber que uso seria feito de seus relatos de memória, se iam passar na televisão, demonstraram grande curiosidade 
sobre a equipe, o pesquisador e os equipamentos. Foi difícil partilhar com eles os objetivos da pesquisa, a necessidade e importância de uma gravação audiovisual que não se destinava, em princípio, a ser veiculada por uma emissora de televisão. Se não vai passar na televisão, para que serve então? Foi difícil, mas não impossível. O primeiro passo foi reconhecer que a relação de pesquisa é um jogo de poder, uma troca, que é iniciada pelo pesquisador, mas que só acontece quando e onde encontra parceiros dispostos à reciprocidade.

No caso desta pesquisa, o fator tempo foi fundamental na construção de uma relação de confiança e respeito mútuo favorável à emergência dos relatos de memória. A pesquisa foi iniciada na cidade de Palestina em 1995 e a última etapa de gravações só aconteceu em janeiro e fevereiro de 2001. Ao longo destes anos, a pesquisadora tornou-se conhecida na cidade, fez amizades, partilhou do cotidiano local, demonstrou interesse pela memória e história locais, saciou as curiosidades sobre si, trocou fotos e presentes, fez um filme e o apresentou na cidade. Pôde observar que, no decorrer do tempo, foram surgindo novas motivações para a emergência dos relatos pretendidos. A mais importante delas foi a percepção local da possibilidade de que os moradores da região do Araguaia que foram presos e torturados durante a guerrilha, bem como seus familiares, venham a ser indenizados pelo Estado por danos e perdas sofridas na época. A Medida Provisória 2.151, de 31/05/2001, regulamenta o regime de anistiado político e torna viável os requerimentos de indenização. Encontra-se atualmente no Congresso Nacional para ser votada e as associações de anistiados políticos estão mobilizadas no sentido de que seja votada como lei. Embora só tenha sido assinada depois de concluída a pesquisa, esta medida provisória já vinha sendo anunciada anteriormente e os moradores da Palestina já estavam mobilizados em torno desta possibilidade, mesmo sem que houvesse ainda o diploma legal que permitisse sua concretização. Ante a possibilidade de serem indenizadas, muitas pessoas que antes não se sentiam motivadas a relatar as experiências dolorosas do tempo da guerrilha, agora tinham necessidade de fazê-lo, como forma de reivindicar um traço de identidade silenciado ou mesmo negado anteriormente, primeiro passo para o requerimento de indenização.

Uma forma de minimizar os efeitos das gravações audiovisuais sobre a relação de pesquisa, utilizada neste caso específico, foi trabalhar 
com uma equipe de realização e um equipamento mínimos durante as filmagens, em 1997 e, posteriormente, fazer as gravações em vídeo usando uma câmara S-VHS, operada pela própria pesquisadora, utilizando sempre a luz natural durante as gravações, prática corrente no campo da Antropologia Visual. Ressalte-se entretanto que, no caso desta pesquisa, esta última opção deveu-se mais a problemas financeiros do que metodológicos, já que a experiência com as filmagens anteriores permitiram concluir que uma equipe reduzida, operando um equipamento leve, afinada com os objetivos da pesquisa e com o pesquisador, pode perfeitamente ser absorvida pela relação de pesquisa. Os efeitos inegáveis que exercem são compensados pela qualidade técnica do material que é filmado ou gravado em vídeo. Ganho técnico este que é fundamental, pois afinal o que fica de mais significativo neste tipo de trabalho são os relatos audiovisuais das memórias dos entrevistados, verdadeiras fontes para a história.

\section{Conclusão}

Gostaria de concluir esta comunicação comentado rapidamente o papel do "encontro" de indivíduos e de culturas na região do Araguaia, tanto no tempo da guerrilha, quanto no tempo da pesquisa, lembrando que, neste caso, falar do "encontro" é falar também do "desencontro" e do "estranhamento".

José de Sousa Martins, na introdução ao livro $A$ chegada do estranho, alerta para a importância de se pensar e discutir nas ciências sociais brasileiras o papel do "desencontro" e do "estranhamento". Segundo ele, o estranho, em princípio, é “o que vem 'de fora', o que pertence a 'outro mundo social', diverso do daqueles que sofrem o seu impacto e vivem a sua presença intrusa e incômoda" (Martins, 1993, p. 11). Sugere que se pense este estranhamento em relação, por exemplo, aos grupos indígenas e de "camponeses". Diz este autor:

"O estranho não é, entre nós, apenas o agente imediato do capital, como o empresário, o gerente e o capataz, mas também o jagunço, o policial, o militar. E, ainda, o funcionário governamental, o agrônomo, o missionário, o cientista social. Embora cada um trabalhe para um projeto distinto, raros 
são os que trabalham pela vítima dos processos de que são agentes" (Martins, 1993, p. 13).

A chegada de pessoas consideradas "estranhas" em Palestina, por razões históricas, suscita dúvidas e curiosidade nos moradores: Quem seriam? O que vieram fazer por aqui? Como recebê-las? São dignas de confiança? Devemos nos solidarizar com elas e abrir o nosso coração? Ou devemos desconfiar delas e delatá-las às autoridades? A fronteira entre a solidariedade e a delação faz-se tênue neste momento. Parte das preocupações com a chegada do "estranho" na cidade pode ser creditada à história da ocupação da região e à guerrilha. A memória local da Guerrilha do Araguaia ficou marcada pela chegada do "estranho" e pela oposição entre solidariedade e delação em relação a ele.

Os moradores de Palestina "estranharam" na época da guerrilha: os guerrilheiros (genericamente tratados como "paulistas" ou "povo da mata"); os militares que reprimiram a guerrilha, em especial os detetives ou "secretas", que assumiam na região identidades falsas e entregavam guerrilheiros e moradores da região às forças da repressão, das quais eram parte integrante; os agentes dos grandes projetos agropecuários e de mineração; os grandes fazendeiros (genericamente conhecidos como "mineiros"). Atualmente “estranham” jornalistas, familiares de ex-guerrilheiros, agentes do Estado encarregados de investigar a guerrilha, pesquisadores (como eu), enfim, todos que chegam ali em busca de relatos sobre a guerrilha.

Entrevistados e entrevistadas mencionaram a delação, quer por parte de vizinhos ou conhecidos, quer por parte dos "secretas" ou detetives, como uma prática comum na região na época da guerrilha. Uma das estratégias das forças da repressão consistia justamente em estimular a delação entre os moradores. Seu Generoso, um dos entrevistados, disse que ainda hoje desconfia de tudo e de todos, inclusive de seus próprios filhos. Quando perguntado sobre os guerrilheiros, se achava que eles podiam ser pessoas boas, ele respondeu:

"Pessoa boa... que a gente não sabe... é igual eu estou falando aqui com você... a gente não conhece ninguém... às vezes joga uma pedra errada... dizendo que é bom e é ruim... ou às vezes diz que é ruim e é bom, né. Acontece. É o que mais acontece. Hoje a gente não conhece nem os próprios filhos. 
Tá dando de comer a ele e na última hora a maldade sai de dentro de casa. Já vi demais, e tá ocorrendo no nosso país inteiro assim, né? Se cria uma pessoa... dá o comer dele, da hora que nasce até... depois é de onde vem o maior perigo... é de dentro de casa..." (Entrevista concedida a esta pesquisadora, em Palestina do Pará, em 07/02/2001)

Como se pode notar, este entrevistado estabeleceu aqui uma relação entre as experiências que viveu no tempo da guerrilha e o momento da pesquisa. A desconfiança que tinha em relação ao "estranho" no passado - o guerrilheiro - foi transferida para o presente, para a pesquisadora. Estes mecanismos de transferência estiveram presentes em várias ocasiões durante a construção dos relatos.

Minha presença em Palestina, para uma pesquisa sobre a guerrilha, atualizou o tempo em que esta aconteceu, por vários motivos. Primeiro há a carga simbólica que foi incorporada localmente aos termos pesquisa e investigação. No tempo da guerrilha os detetives faziam pesquisa e investigação, com o objetivo de instruir os agentes da repressão. Quem foi "investigado" ou "pesquisado" na época, geralmente foi preso e torturado. Depois, eu usava gravador, máquina fotográfica, câmara e outros equipamentos de gravação audiovisual, que também eram utilizados pelos militares que reprimiram a guerrilha. Um dos entrevistados disse que "quando uma pessoa era presa, era investigada, fotografada, entrevistada, igualzinho como você está fazendo aqui comigo, agora" (Entrevista concedida a esta pesquisadora, em Palestina do Pará, em 101/02/2001, pelo senhor Cinésio). Finalmente, o fato de vir de Brasília, de onde veio também a repressão, ajudou a reforçar este tipo de transferência.

O tema da delação traz o da solidariedade, assim como o do "estranhamento" traz o do "encontro". Dona Maria Amélia, esposa do senhor Antonhão, que também foi preso e torturado, conta que no dia em que seu marido foi preso ela foi amparada e ajudada por uma vizinha. Esta correu o risco de também ser objeto de suspeição por ajudála em um momento difícil. Dona Felicidade, esposa do Baiano, fala que foi ajudada por amigos enquanto ele esteve preso e, depois, quando estava muito doente e, também, em São Paulo, no Hospital das Clínicas, onde seu marido foi operado de um tumor no cérebro. Ali ele foi ajudado por uma enfermeira de Marabá que trabalhava naquele hospital. 
Durante a pesquisa, entrevistei um senhor conhecido como José de Belém, que nasceu no interior do Piauí, na mesma cidade onde nasci. Enquanto o entrevistava, conversamos sobre lugares de memória que temos em comum, o que contribuiu para diminuir sua desconfiança em relação a mim e aos objetivos da pesquisa.

Identificação semelhante ocorreu em relação às mulheres. Para mim, foi mais fácil entrevistá-las do que os seus maridos, provavelmente por ser mulher e mãe de família como elas. Os entrevistados sempre me perguntavam se tenho família. Estranhavam que, tendo família, fosse capaz de deixá-la em Brasília e ir para a Palestina. Algumas mulheres me perguntaram se não tinha medo de deixar marido e filho sozinhos enquanto estava na Palestina. Estranhavam também o fato de meu marido concordar com minhas viagens para a região. Demonstraram curiosidade em relação à minha família. Para saciar parcialmente esta curiosidade, mostrava fotos de meus familiares. Elas também me mostravam fotos dos seus. Este momento de compartilhar a imagem fotográfica dos familiares foi muito rico e reforçou os laços de intimidade e confiança entre pesquisador e entrevistados. Uma família digna tem o seu álbum de fotos. Eles também gostavam de olhar as fotos que fiz deles e da paisagem local e ficavam encantados quando eram presenteados com elas. Gostam de se ver retratados, gravados em vídeo, filmados, embora geralmente fiquem constrangidos na hora do clic, da filmagem ou da gravação.

\section{Referências bibliográficas}

BENJAMIN, Walter. O narrador: considerações sobre a obra de Nikolai Leskov. In: BENJAMIN, Walter. Magia e técnica, arte e política: ensaios sobre literatura e história da cultura. São Paulo: Brasiliense, 1987, p. 197-221.

BOURDIEU, Pierre. A miséria do mundo. Petrópolis: Vozes, 1997.

CABRAL, Pedro Corrêa. Xambioá: Guerrilha do Araguaia. Rio de Janeiro: Record, 1993.

CANDIDO, Antonio. Os parceiros do Rio Bonito: estudo sobre o caipira paulista e a transformação dos seus meios de vida. São Paulo: Duas $\mathrm{Ci}$ dades, 1982.

CURTIUS, Ernest Robert. Literatura européia e Idade Média latina. Brasília: 
Instituto Nacional do Livro, 1979.

LACERDA, Sonia. História, narrativa e imaginação histórica. In: SWAIN, Tânia Navarro (org.). História no plural. Brasília: Universidade de Brasília, 1994, p. 9-42.

MARTINS, José de Sousa. A chegada do estranho. São Paulo: Hucitec, 1993. MIRANDA, Nilmário e TIBÚRCIO, Carlos. Dos filhos deste solo. Mortos e desaparecidos políticos durante a ditadura militar: a responsabilidade do Estado. São Paulo: Boitempo / Fundação Perseu Abramo, 1999.

POLLAK, Michael. La gestion de l'indicible. Actes de la Recherche en Sciences Sociales, Paris, (62/63) p. 30-53, jun. 1986.

POLLAK, Michael. Memória e identidade social. Estudos Históricos, Rio de Janeiro, v. 5, n. 10, p. 200-15, 1992.

RICOEUR, Paul. O conflito das interpretações: ensaios de hermenêutica. Rio de Janeiro: Imago, 1978.

SILVA, Dácia Ibiapina da. Memórias da Guerrilha do Araguaia: relatos de moradores de Palestina do Pará. Tese de doutorado. UFRRJ / CPDA, 2002.

STONE, Lawrence. The revival of narrative. Past \& Present, (85), p. 3-24, 1989.

Resumo: Ao realizar uma pesquisa sobre as memórias da GuerriIha do Araguaia com moradores da cidade de Palestina do Pará, situada na região onde aconteceu este movimento guerrilheiro no período de 1972 a 1974, a opção por gravar os relatos de memória dos entrevistados em vídeo ou película mostrou-se adequada. A natureza traumática do que estava sendo relatado, bem como a dificuldade que os narradores tinham de verbalizar as dores e perdas sofridas no passado, no tempo da guerrilha, dito por eles como tempo de "sofrimentos" e de "prejuízos", levou-os a utilizar outras formas de expressão e de comunicação, para além do texto verbal: o olhar, os gestos, as pausas, os silêncios, bem como a repetição de palavras e expressões. A linguagem audiovisual foi capaz de apreendê-las, ampliando assim as possibilidades análise e interpretação dos relatos de memória construídos durante a pesquisa.

Palavras-chave: Relatos de memórias traumáticas; história oral; relatos audiovisuais de memória.

Oral History; Orality and Audiovisual in the Construction of the Traumatic Memory Narratives

Abstract: On carrying out a research work into the memories of the Araguaia guerrilla warfare among inhabitants of Palestina do Pará, a small city in the region of the struggle that took place be- 
tween 1972 and 1974, the option to record the accounts of the interviewees on video and film revealed to be an appropriate choice. The traumatic nature of their narrative as well as their inability to verbalize their losses and misfortunes at the time of the conflict, a time of "suffering and harm" in their saying, lead them to express and communicate beyond the verbal text: sight, gestures, pauses, silence, repetition of words and expressions. The audiovisual language was capable of apprehending their meanings, widening the scope for analysis and interpretation of the memories built up during the research.

Keywords: Traumatic memory narratives; oral history; audiovisual memory narratives. 